
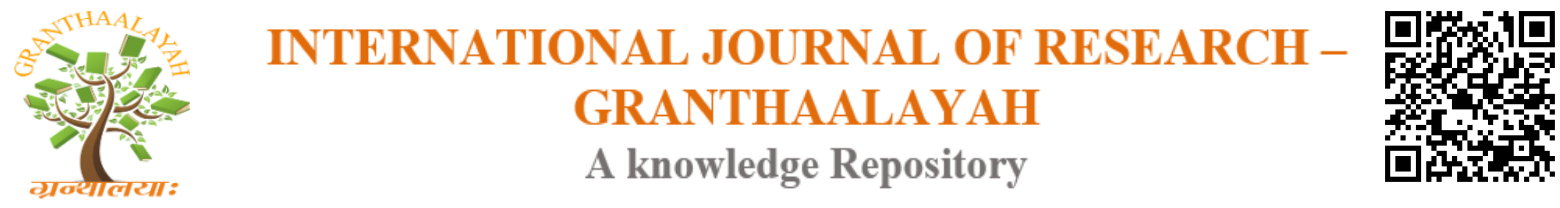

Management

\title{
THE INVOLVEMENT OF AFRICA IN THE ADMINISTRATION OF THE ONE BELT ONE ROAD INITIATIVE: AN ANALYSIS
}

\author{
Zainab Gimba *1 \\ ${ }^{* 1}$ Department of Public Administration, University of Maiduguri, Nigeria
}

\begin{abstract}
The paper examines the new Chinese global initiative of the one belt one road, looking at the new Silk Road from the administrative and beneficial connectivity. Using the secondary methodology, findings show that, the initiative has not really included Africa in its connection, as only Kenya and Egypt are fully integrated. The paper concludes that Africa needs more representation and inclusivity to have a very inclusive global initiative. The paper also recommends that, china should not make Africa and other Asian nations dumping grounds for its finished goods, among other things.
\end{abstract}

Keywords: Involvement; Africa; Administration; One Belt One Road; Initiative; Analysis.

Cite This Article: Zainab Gimba. (2018). "THE INVOLVEMENT OF AFRICA IN THE ADMINISTRATION OF THE ONE BELT ONE ROAD INITIATIVE: AN ANALYSIS." International Journal of Research - Granthaalayah, 6(2), 224-233. https://doi.org/ 10.5281/zenodo.1194658.

\section{Introduction}

In a span of 3 decades, China has transformed from an agricultural, self-contained and inward looking state into a global economic power house second only to the United States (Cheung \& Lee, 2015). In line with her growing stature in the international system, China has sought to exert influence on the global stage, from Latin America, Middle East, South East Asia, to Africa (Freidberg, 2005). One way of achieving this and as part of China's global grand strategy is the 21st Century Silk Road Economic Belt Initiative, informally known as One Belt, One Road ${ }^{\text {ee }}$ In the same vain, Sino-African relations have grown exponentially since the 1955 Bandung conference. According to the 2011 economic outlook report, China has surpassed the US as Africa's single largest trading partner in volumes from a paltry USD1 billion in 1980 to USD200 billion in 2014 (Anami, 2016), leading to critics and supporters to hail and question this new partnership between Africa and China at the same time. This paper seeks to re-look at this partnership through the lenses of the One Belt, One Road ${ }^{\text {ee }}$ Initiative. It seeks to find answers to the extent of Africa's involvement in China's global strategy, its status in Africa, projected benefits and how they will be distributed between China and Africa, and future prospects. By answering these questions, the researcher hopes to shade more light on the position Africa holds 
in China's plans, China is important to Africa, but is Africa also important to China? Or is it a case of same path, different actors in perpetuating the bit-part player and down-trodden supplier of raw materials that Africa was relegated by the Western world, only that now, China is involved. China's deepening engagement with Africa hasleto it being labelled as a new colonialism and or neo imperialism (Naidu, 2007)

\section{Material and Method}

The paper applies the secondary method of data collection to reach to the findings of the paper. The secondary methodology encompasses the application of text books, journals, newspapers, magazines and periodicals in getting the relevant information needed. The paper also adopts the internationalist theory as theoretical framework. The theory sees cooperation as indispensable among states, which brings prosperity, security and cement the spirit of interactions. This will further bind nation-states together as a new strategy of global integration.

\subsection{Theoretical Framework}

\section{The Internationalist Theory}

The internationalist theory is an off-shoot of the school of liberalism, just like functionalist and neo-functionalist theorists. The internationalists give no condition to regional integration and believe that integration will bring more interdependence and cooperation among nations (Sheriff, 2013). The internationalists see substance of globalization, free trade and open market economic system as binding principles that can deepen cooperation and interdependence. This will also avoid conflict, tension and confrontation among member-states. If liberal-institutionalism should support internationalism, it becomes noted that regional integration is to be conducted under the watch of some binding rules and regulations that all members must have to respect (Sheriff, 2013).The 'One Belt, One Road' initiative as indeed an internationalized initiative that cutsacross three continents and aimed at affecting about $63 \%$ of the global population; such an initiative should have binding principles that will guide the initiator - China on what she must and must not do during the course of the implementation of the initiative. As it did have a memorandum of understanding with Egypt, same should be done with Kenya and Djibouti to enable her have a clear-cut and defined rules of what it aimed to achieve and also gain in these countries in Africa.

\subsection{Literature Review}

The original Silk Road was established over 2,100 years ago during the Han Dynasty (206 BC$24 \mathrm{AD}$ ) to promote trade and cultural development between China, Asia, Africa and Europe and covered over 7,000km (Li et al, 2015). The New Silk Road Economic Belt "christened fondly as One Belt One Road" initiative or Yídàiyílù was introduced by China's President Xi Jinping as the center-piece of his foreign and economic policy in 2013. First to be introduced in September 2013 at Nazarbayev University in Kazakhstan was the Silk Road Economic Belt followed closely in October by the second part, the Maritime Silk Road announced in Indonesia (Ravi, 2016). It is by far the most significant and far-reaching project China has ever embarked on (Varlare \&Putten, 2015). However, first to moot the idea was a Chinese scholar, Wang who in 2012 wrote an opinion article to the Global Times conceptualizing this ( $\mathrm{Li}$, et al 2015; Callahan, 
2016). The blue print dubbed "Chinese Marshall Plan" by some critics and defended by supporters, will define his administration and legacy. The One Belt One Road project or OBOR is essentially comprised of two interdependent and interrelated concepts; the "Silk Road Economic Belt" and the "Maritime Silk Road". Essentially, the belt is comprised of a network of roads, rails, power grids and gas pipelines that run over land from Central China in Xian, the capital of Shanxi Province through Central Asia, to Moscow, Rotterdam and Venice (EURASIA). This conglomerate of infrastructural projects will therefore pass through a number of countries. The Maritime Silk Road (MSR) on the other hand is its oceanic counterpart. This involves the construction of a network of sea ports in the South China Sea, Indian Ocean and the South Pacific Ocean. It will essentially connect South East Asia, Oceania, East Africa and North Africa through the Mediterranean. The core pillars of the initiative are "promotion of policy coordination, facilitating connectivity, unimpeded trade, financial integration, people-to-people bonds" (Varlare\&Putten, 2015). The African section of the belt and road is of concern for this paper. It covers three countries; Kenya, Djibouti and Egypt.

\section{One Belt, One Road in Numbers}

The Initiative cuts across 3 continents of Asia, Europe and Africa. It targets 4.4 billion people in 67 countries directly representing $63 \%$ of the total global population. At a GDP of 2.1 trillion US dollars, this represents 29\% of the total world GDP (Leverett et al, 2015 as quoted in Fasslabend, 2015). Two financial sources, the Asia Infrastructural Investment Bank (AIIB, USD100 billion) and the Silk Road Fund (SRF) with a funding portfolio of USD40 billion will bankroll the bulk of the projects within the belt and road (Cheung \& Lee, 2015). The project impact as a conclusion of these numbers is therefore substantial.

\section{Status of 'One Belt, One Road' in Africa}

According to Xinhua News Agency, 3 countries in Africa are directly involved in the belt and road initiative; Kenya, Djibouti and Egypt. However, the extent of their involvement is unclear, with many documents indicating Egypt as the sole African state to be involved in this initiative. Various factors have been attributed for the inclusion of these sole 3 African states into the center piece of China's 21 st Century diplomacy;

\section{Results and Discussion}

World politics has been characterized by power politics. The horn of Africa region and the Suez Canal has been traditionally a Western-controlled zone with the US and her allies being the primary guarantor for maritime security. Whichever powerful state controls the security of that region, also controls the maritime trade routes between Asia, Europe and Africa. Egypt and Djibouti, two of the three African states part of the OBOR are strategically located at the heart of global geo-politics playground. Djibouti is quite unique as it now hosts military bases for the US, France and now China. While the fight against pirates has often been cited as the propellant behind this, one can't quite push the power struggles as being the true variable for these great powers having such a heavy military presence in the region. The entry into Djibouti and the region by China could tilt and realign security partnerships that have underpinned global order since 1945 (The Sun, 22nd August, 2016). 
For Egypt, its strategic geographical location at the Suez Canal gives it an indispensable status, explaining why it's the only African nation to officially sign bilateral agreements with China on One Belt, One Road. The initiative simply cannot afford to exclude Egypt. On the other hand, the inclusion of Djibouti has been a result of logical assumptions than from official pronouncements. This can purely be explained under the quest for global dominance and the geopolitics of the horn of Africa as stated earlier. With 30\% of world shipping going through the entrance of the Red Sea from the Indian Ocean and on to the Suez Canal, Djibouti and Egypt are very critical (Financial Times, April 1, 2016). Though Kenya is on the semi-official route map of the OBOR, no official declaration has been made by both governments. Its inclusion makes an interesting case as no direct security, political, economic or trade link can be noticed from the onset. Kenya is neither resource rich, nor is it a high trading partner to Beijing. Its location along the East African Coast of the Indian Ocean, in relation to some key China partners however, can give pointers into why it was co-opted into OBOR. Geographically, Kenya borders South Sudan which is a key exporter of oil to China. With the violence between North and South Sudan being far from over, the need for an alternative route to export oil to China becomes necessary (Callahan, 2016). Kenya offers this alternative hence perhaps explaining her inclusion in OBOR.

\subsection{Core Projects and Projected Impact by Country}

\subsubsection{Projected Impact in Kenya}

With a GDP of 63.40 billion US dollars and a population of 46 million as at 2015 (World Bank, 2016), Kenya is the point of entry for the maritime silk road into Africa from Asia. Through an analysis of documents and news items, the projects linked to OBOR initiative could be deciphered. Amongst the core projects are upgrading of the Mombasa Port, building of a new ultra-modern port in Lamu, building a new standard gauge railway line linking Mombasa port, the capital Nairobi, and the land locked neighbouring countries. The railway and pipeline is envisaged to link the ports in Kenya, to oil fields in South Sudan and Uganda, while also joining with Ethiopia, Rwanda, Burundi facilitating exports for these countries products. The railway line is expected to cover $2,700 \mathrm{~km}$ with phase I, the 610 kilometer stretch from Mombasa to Nairobi construction underway. The estimated cost is 25 billion US dollars, with China's Exim Bank being the principal financier covering $90 \%$ of the costs. (Cascais, 2015) Financing for the construction of the new port and the pipeline is unclear, with ambiguity on what role the OBOR institutions AIIB and SRF have in the Kenyan chapter of this initiative. Worth noting here is the lack of a clear bilateral agreement specifically highlighting how Kenya and China will work towards the new Silk Road venture.

In Kenya the most salient impact is on the infrastructural front, with an estimated foreign direct capital investment of USD25 billion on the railway modernization, pipeline from Kenya to South Sudan at USD4 billion, while Lamu port and associated infrastructure investment will be USD27 billion when complete (Daily Nation, March 6 2016). This is capital which Kenya as a country cannot raise, but OBOR and its associated financial institutions can come in and bridge the deficit. When fully operational, these projects will benefit oil export from Uganda and South Sudan, whose conflict with Sudan has led to challenges on exporting her oil to China and other countries. At the height of successful oil production by Sudan before the conflict, China imported 5\% of its oil from the country (Shinn, 2014). However, due to the conflict and resultant 
separation between the North and South, Sudan retained $25 \%$ of the oil fields, while South Sudan retained $75 \%$. With conflict still persisting, China's investment in Sudanese oil is not bearing fruits as optimum production of oil has not been attained. The Kenyan route therefore offers an opportunity for South Sudan to export her oil to China without being frustrated by the North, a win-win situation for South Sudan and China. On the same breath, discovery of oil fields in Northern Uganda also diversifies oil import source markets for China. Uganda can export her oil through Kenya, as she is landlocked. With the Kenyan route secure, China has also taken care of any prospects for future OBOR expansion into the African hinterland, while getting a strategic port of call in the event of any security challenge in the horn of Africa region.

\subsubsection{Projected Impact in Egypt}

Tiezzi (2016) argues that, without Egypt, the Maritime Silk road is unfeasible. This makes Egypt an indispensable member of OBOR. In fact, its centrality to the initiative explains why it's the only African country whose President Abdel Fattah Al-Sisi formally signed a memorandum of understanding with China with regards to the OBOR initiative in January 2016. The Suez Canal is the transit point between the Indian Ocean and the Mediterranean Sea. As an added sweetener financing to the core project with the road China gave USD1 billion to Egyptian central bank, and USD700 million loan to the National Bank. Separately, the expansion of the Suez Canal over a 10-year period, and building of a new administrative capital for Egypt have been initiated, with the colossal sums of USD230 million and USD45 billion respectively being the costs that China will foot.

The infrastructural impact has already been highlighted. However, aside from this, the OBOR initiative in Egypt is expected to have other positive impacts. The China-Egypt Suez Economic Zone a result of the initiative will create over 10,000 jobs for Egyptians. Egypt will also get a brand new administrative capital aside from Cairo. President Al-Sisi gets to have a partner in China for his ambitious projects. On the Chinese side, with the completion and operation of the Suez Canal falling under Chinese control, this comes with substantial influence on power and security dynamics within the region previously dominated by the West. Tiezzi (2016) says "imagine the New Suez Canal, completed with Chinese financing and managed by a Chinese company as the gateway between Europe and Asia". The benefits will be immense. Chinese footprints in matters of global security, and specifically the Mediterranean region will be felt.

\subsubsection{Projected Impact in Djibouti}

The involvement of Djibouti in OBOR is not as clear as Egypt's. However, there are 14 mega projects funded by China as part of the belt and road initiative, worth 9.8 billion US dollars. These are aside from the military base at port Dolareh, which is the main investment aimed at cushioning the maritime routes security interests in East Africa and the Indian Ocean (Edens, 2015). This base is of strategic importance to China as it is the first Chinese military base of any kind, outside of Chinese soil (Linehan, 2016). Officially, the base is to shove up anti-piracy in the area, but speculation is rife that it could be used to guard the trade artillery linking Asia and Europe, through the Suez Canal which China is modernizing. The base will act as comprehensive supply point ${ }^{\text {ee }}$ for Chinese ships, with berths for loading and off-loading cargo. The estimated cost for construction of the military base is USD590 billion, and will mainly be supported by 
China (Liu, 2016). Military expert Li Jie summarizes the significance of this undertaking, the depot will play an important role in the one belt, one road strategy and enable China to respond rapidly to emergencies in North Africa, Middle East and South Asia (Cheung \& Lee, (2015).

With a population of 887,900 in 2015 , and a combined GDP of 1.589 billion US dollars, Djibouti does not offer much in terms of market and trade for Chinese products. Other reasons besides trade therefore informed China's decision to enter Djibouti into the MSR initiative. China's entry into the country with a military base makes Djibouti to be the most important ally in political and security matters for 3 of the 5 permanent members of the UNSC. Aside from China, Djibouti also hosts a French military base and the biggest US base in Africa, Camp Lemonnier. Russia is also thought to harbor ambitions of setting up a base here (Edens, 2015). This has propelled the small horn of Africa nation to the coveted status of being almost invincible in world politics. Aside from the politics, economically, the USD1.589 billion dollar GDP African country (World Bank, 2015), is in dire need of capital. As part of the OBOR financing, China will inject 9.8 billion US dollars to infrastructural projects other than the military port base, which will cost a further USD590 billion. This is a substantial improvement in its infrastructural investment. China on the other hand, gets a strategic position in the geo-politics of North Africa, Middle East and Europe, a sphere previously dominated by the US. (Linehan, 2016) It's reported that China's entry into Djibouti was actively opposed by the US, even going as far as proposing the US to double its rent for Camp Lemonnier, due to it's implications to the geo-politics of the region (Colombant, 2012). China has therefore clearly scored one against the US in the horn of Africa. This, coupled with her control of the Suez Canal, will give her immense powers.

\subsubsection{OBOR in Africa: Opportunities and Challenges}

As earlier shown, Africa's inclusion in the Belt and Road Initiative is minute. While much has been said about growing Sino-African relations, a study of Africa in China's most ambitious ever project does not support the importance that China places in Africa as a region and continent. Three countries out of 67 in the OBOR do not in any way support the claim that Africa is an important ally to China. In fact, China's 2015 Africa policy paper do not mention One Belt, One Road $^{\text {ee }}$ in Africa. In its current states, what opportunities and challenges does OBOR have in Africa?

\subsubsection{Opportunities Current Infrastructural Projects in Africa}

The $1,780 \mathrm{~km}$ Tanzania Zambia Railway line (TAZARA) has symbolized China's presence in Africa since the 1970's. Currently China is involved in numerous mega infrastructural projects in Africa. For purposes of this paper, some of those which lie within the mandate of OBOR will be highlighted. Top on the list is the 2,700km East African Railway line. This includes Kenya, Uganda, Rwanda, Burundi and South Sudan. As indicated earlier, extent of involvement of OBOR affiliated institutions in financing the Kenyan part are not clear, though China's Exim bank has been linked. (Friedman, 2009) Another major railway project is the $1,315 \mathrm{~km}$ KanoLagos railway line in Nigeria, the 1,302km Bengue railway line in Angola (which brings to total $4,000 \mathrm{~km}$ railway in Angola constructed by China), 560km Belinga-Santa Clara railway in Gabon, $172 \mathrm{~km}$ railway in Libya and $430 \mathrm{~km}$ rail in Mauritania to name but a few. To put this into perspective, the entire African rail network is 50,000km (Executive Research Associates, 2009). 
On the other hand, China is constructing port facilities in Kenya, Tanzania, Gabon, and Djibouti among others, with most road construction being handled by Chinese contractors, using Chinese financing. The 1,302km Angola railway line will be linked with Angola-Zambia and TAZARA in future. On port construction, China is involved in construction of the Lamumega port in Kenya, Bagamoyo port in Tanzania, Santa Clara deep water port in Gabon amongst others (Greig, Mason, \& Hamner, 2016). It's safe to say even without OBOR therefore, China is heavily involved in opening up Africa.

Firstly, with China involved in all these infrastructural projects in Africa, coupled with OBOR's vision for improving connectivity among countries, the initiative will offer a centralized, clear vision, and concerted effort in streamlining infrastructural development in Africa. A case in point is the railway line in Angola which is complete on their side of the border, but under-utilized because neither Democratic Republic of Congo nor Zambia have linked up to connect to the port, hence hindering efforts to export their products. Secondly, capital for infrastructural development in Africa comes from various Chinese bank loans under individual bilateral agreements entered into by these countries. Through OBOR, the capital inflow can be clearly centrally monitored through the AIIB and the SRF. This need is further strengthened with China signing a memorandum of understanding with the African Union (AU) in January 2015 to connect all 54 countries with high speed rails, ports and roads. The traditional ,equatorial land bridge $^{c e}$ which is the natural trade route between East and West Africa can be a good starting point for OBOR in Africa expansion. This route begins in Kenya, Uganda, Rwanda, Burundi, the Congo's, Central African Republic, to the West in Douala Cameroon. (Kennedy \& Parker, 2015) In the course of this study, the following results were found which will be raised and discussed therein. They are thus:

The initiative of One Belt One Road cuts across three continents of Asia, Europe and Africa, targeting 4.4 billion people in 67 countries representing $63 \%$ of the world population. This initiative is a laudable one given that it will attend to the needs of both the industrialized and developing countries of the world with the needs of these countries met if the initiative is properly attended to. Three countries in Africa are directly involved in the belt and road initiative - Egypt, Kenya and Djibouti - the extent of this involvement is unclear with many documents indicating Egypt as the sole African state to be involved in the initiative. This also plays a similar game with the methodology and operational style of the West that brings up lofty projects that are aimed to developed the developing African countries when in truth, they are meant to compound the woes of underdevelopment of the African continent which accepts there economic blueprints of development.

Egypt and Djibouti are strategically located at the heart of the global geo - politics playground, hence the interest from China to integrate them in the OBOR initiative. Given that China has announced her stead and prominence in international politics, the need to follow up in her economic strength and dominance through making in-road to the economic assistance of Africa and partnership to outwit the West has made her invest the much she can into the development of the countries in Africa. Kenya offers an alternative route to China to import oil from South Sudan without having to pass through North Sudan that will not easily be a conducive route to admissible to the economic interest and development of the Southern Sudan. Egyptian President, Abdel Fattah Al-Sisi is the only African country or president to have signed a memorandum of 
understanding with China with regards to the OBOR initiative in 2016; this goes to show that the initiative in other countries in Africa are either put in place to make these other countries have some false hope or ward-off the West from trampling on their interest in those countries.

\section{Conclusion and Recommendation}

The one belt, one road initiative is indeed a beneficial one for the African countries who are lucky to be chosen for the initiative as it will give rise to infrastructural development of face-lift in these African countries and will also assist in the industrialization and creation of employment opportunity in these African countries, like the case of the Suez Canal in Egypt.

The initiative is also aimed at establishing China global economic hegemony through the establishment of her presence in three of the five continents in the world, and which is aimed at getting involved more than half of the world population as beneficiaries of the initiative. It is indeed a laudable initiative that will threaten the West to seat up in drawing up their own economic blue-prints for their countries and the world.

It is recommended that given the way and manner Kenya and Djibouti's initiative was drawn without any formal agreement through a memorandum of understanding, China can decided to abandon the initiative in these countries and will not be held liable to it given that no document was signed as a binding force on them, therefore, Kenya and Djibouti must do well to insist on this nature of agreement for the initiative to be seen and recognized as a valid one.

China must be seen as operating the same economic line of trade as the west that has not be favourable to Africa and Asia in the past as this will make these countries to have the same distrust as it presently has for any economic policy coming from the west.

China must go beyond just three countries in Africa to enable her drive to fully industrialize Africa and Asia through the initiative being felt and achieved.

China must not use this initiative to make these African and Asian countries a site for the dumping of her waste products or flood the markets of these countries with substandard cheap products from their countries; rather it should establish their industries in these countries to enable the increase of employment opportunity for citizens of these countries - 'Chinalization of African Initiative'

\section{References}

[1] Achuka, V. (2016): "Kenya to Soldier on Even as Partners Pull out" Daily Nation March 3, 2016.http://www.nation.co.ke/news/Kenya-to-soldier-on-even-as-partners-in-Lapsset-pullout/1056-3104 914-2mkaoy/index.html

[2] Anami, L. (2016): in an article in The Standard Newspaper reports how the government was sued by environmental activists for not undertaking an impact assessment on the section passing through the national park. The case is still going on.

[3] Anami, L. (2016): "Tribunal Blocks Standard Gauge Railway Route Through Nairobi National Park", The Standard, September 20th, 2016. www.standardmedia.co.ke 
[4] Callahan, W.A. (2016): "China's Asian Dream": The Belt Road Initiative and the new regional order"e, Asian Journal of Comparative Politics, Vol.1, No. 18

[5] Cascais, A. (2015): "Are Africaes Railroads on Track for Sustainable Development? DW Akademie, July 10, 2015 www.dw.com/en/are-africas-railroads-on-track-for-sustainabledevelopment/a18570402

[6] Cascais (2015): in his article gives a variety of reasons why Africa's rail is not advantageous. Cheung, F \& Lee, A (2015), "Thirty Years of Unprecedented Growth", CLSA www.clsawww.businessdailyafrica.com.com

[7] Colombant, N. (2012): "Growing Sudan, South Sudan Oil Impasse Has High Stakes", Voice of America, February 4 2012, http://www.voanews.com/english/news/africa/Growing-Sudan-SouthSudan-Oil-Impasse-Has-High-Stake s-138712714.html.

[8] Edens, R. (2015): “Chinae s Naval Plans for Djibouti: a Road, a Belt, or a string of Pearls?” The Diplomat, www.thediplomat.com May 14, 2015.

[9] Friedman, T.L. (2009): “Our One Party Democracy”, New York Times, September 8, 2009.

[10] Greig, J.M., Mason, T.D. \& Hamner, J. (2016): "Win, Lose or Draw in the Fog of Civil War", Conflict, Management and Peace Science, pp. 1-21

[11] Kennedy, S. \& Parker, D. A. (2015): "Building China's One Belt, One Road”,Center for Strategic and International Studies, http://csis.org/publication/building-chinas-one-belt-one-road

[12] Large, D. (2008): Beyond the Dragon in the Bush: Study of China-Africa Relations ${ }^{\text {ee }}$, African Affairs, Vol.107, No.426, pp.45-61.

[13] Li, P et al (2015): Building a new Sustainable "Silk Road Economic Belt", Environmental Earth Sciences, Vol.74, pp.7267-7270.

[14] Liang, M. (2011): "China-Africa Trade: from China and Africa's Global Perspectivese,

[15] Linehan, M (2016), "China"s Belt and Road Strategy: Reality vs Ambition" Rising Powers https://rising-powers.com/2016/04/10/chinas-belt-and-road-strategy-reality-vs-ambition/

[16] Liu, Z. (2016): "China starts work on Horn of Africa Military Base in Djibouti, Defense ministry confirms", South China Morning Post http://www.scmp.com/news/china/diplomacydefence/article/1917210/china-starts-work-horn-africa-milit ary-base-djibouti

[17] Lu, Y. (2011): "China"s Trade Rush with Africa", Capital Week, www.focac.org/eng/

[18] Manson, K. (2016): "China Military to Set Up First Overseas Base in Horn of Africa", Financial Times, April 1, 2016 https://www.ft.com/content/59ad20d6-f74b-11e5-803c-d27c71117d132.

[19] Ministry of Foreign Affairs and the Ministry of Commerce of the People's Republic of China, (2015, March), Vision and Actions on Jointly Building Silk Road Economic Belt and 21st Century Maritime Silk Road

"e http://en.ndrc.gov.cn/newsrelease/201503/t20150330_669367.html.Shinn, D (2014), "Africa Tests China"s Non-Interference Policy", China US Focus, http://www.chinausfocus.com/foreignpolicy/africa-tests-chinas-non-interference-policy/\#sthash.8GwI3qi 8.dpuf

[20] Munyanga, P. (2016): "Stop SGR until land Owners are Paid, court rules", Business Daily, July 21st, 2016 www.businessdailyafrica.com

[21] Munyanga, P Business Daily (July 21, 2016) reported suspension of the project when one land owner went to court. Construction stopped until compensation was effected.

[22] Naidu, S. (2007): "The Forum on China-Africa Cooperation (FOCAC): What Does the Future Hold?” China Report, Vol.45, No.3, pp.283-296.

[23] Ndlovu-Gatsheni, S.J. (2012): "Beyond the Equator there are no Sins Coloniality and Violence in Africa", Sage, Vol. 28, No.4, pp.419-440.

[24] Nye, J. (1990): “Soft Power”, Foreign Policy, No.80, pp.153-171.

[25] Olander, E. Staden, C. \& Tiezzi, S. (2016): "Inside Africa"s Role in China "s Ambitious "One Belt, One Road" Initiative, The World Post http://www.huffingtonpost.com/eric-olander/africachina-one-belt-one-road-initiative-_b_9471982.html

[26] Pigato, M. \& Tang, W. (2015) :"China and Africa: Expanding Economic Ties in an Evolving Global Context”, Investing in Africa Forum, Addis Ababa, March 2015. 
[27] Ravi, B. (2016): “The Silk Road as a Global Brand”, China Report, Vol.52, No.1, pp. 45-52.

[28] Sandrey, R. et al (2016): "Chinese Imports from Africa: the impact of the recent commodity price decline", Tralac Working Paper, No.US16WP04/2016, Trade Law Centre.

[29] Sheriff, G. I. (2013): Lectures on International Economic Relations: From Economic Nationalism, Internationalism to Structuralism. Abuja, Richardmore Press.

*Corresponding author.

E-mail address: sherfboy@ yahoo.com 